Biol. Stud. 2020: 14(4); 49-58 • DOI: https://doi.org/10.30970/sbi.1404.634

www.http://publications.Inu.edu.ua/journals/index.php/biology

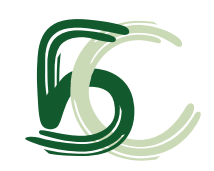

UDC: $597.6 / .9:[502.211: 061](477.83)$

\title{
FAUNISTIC REVIEW OF AMPHIBIANS IN PROTECTED AREAS OF UKRAINIAN ROZTOCHIA
}

B. O. Andriishyn

Ivan Franko National University of Lviv, 4, Hrushevskyi St., Lviv 79005, Ukraine e-mail: bohdanoksalat@gmail.com

Andriishyn B.O. Faunistic review of amphibians in protected areas of Ukrainian Roztochia. Studia Biologica, 2020: 14(4); 49-58 • DOI: https://doi.org/10.30970/sbi.1404.634

Background. Study of amphibian fauna as a necessary component of ecosystems is always relevant and requires a regular renewal of information, especially in protected areas. We conducted a field investigation of amphibians, a literature review and an inventory of the collections of herpetological funds in relation to three protected areas: the Roztochia Biosphere Reserve, the Yavorivskyi National Park, and the Cholgini Ornithological Reserve.

Materials and Methods. The field study was performed by classical methods: route method with manual catching and with herpetological nets, vocalization method, sampling of amphibians crushed on the road, and catching individuals with frog fences. We also analyzed the literature and amphibian collections in the Zoological Museum of Ivan Franko National University of Lviv.

Results. According to the available literature, the amphibian fauna of these three areas under protection is similar and typical of this region. The results of our field research slightly differ from the literature data, thus, there is a need for further studies. On the study areas, we found 12 species of amphibians, which is more than half of the number of amphibian species in Ukraine, in particular: Smooth Newt Lissotriton vulgaris, Great Crested Newt Triturus cristatus, Fire-bellied Toad Bombina bombina, Eastern Tree Frog Hyla orientalis, Common Spadefoot Toad Pelobates fuscus, Common Toad Bufo bufo, Green Toad Bufotes viridis, Common Frog Rana temporaria, Moor Frog Rana arvalis, Marsh Frog Pelophylax ridibundus, Edible Frog Pelophylax esculentus and Pool Frog Pelophylax lessonae. We detected 2 species of Caudata and 10 species of Anura. 10 species of amphibians were found in the Roztochia Biosphere Reserve, 5 species - in the Yavorivskyi National Park, and 9 species - in the Cholgini Ornithological Reserve.

Conclusions. According to the field results, 4 species inhabit all three protected areas - Common Toad, Eastern Tree Frog, Marsh Frog and Edible Frog. A relatively

(ㄷ 2020 B. O. Andriishyn; Published by the Ivan Franko National University of Lviv on behalf of Біологічні Студії / Studia Biologica. This is an Open Access article distributed under the terms of the Creative Commons Attribution License (http://www.budapestopenaccessinitiative.org and Creative Commons Attribution 4.0 License), which permits unrestricted reuse, distribution, and reproduction in any medium, provided the original work is properly cited.

ISSN 1996-4536 (print) • ISSN 2311-0783 (on-line) • Біологічні Студії / Studia Biologica • 2020 • Том 14/№ 4 • С. 49-58 
small variety of amphibians found in the Yavorivskyi National Park can be due to the homogeneity of habitats and a proximity of one of the largest military proving grounds in Europe, which limits amphibians in choice of the reproductive and trophic habitats. These habitats deserve special attention because of their fast degradation for the last 10 years.

Keywords: amphibians, fauna, protected areas, Ukrainian Roztochia, the Roztochia Biosphere Reserve, the Yavorivskyi National Park, the Cholgini Ornithological Reserve

\section{INTRODUCTION}

Fauna and animal inventory in biotopes with different levels of anthropogenic pressure is always a topical aspect in zoological research. Protected areas deserve special attention as complexes of habitats for populations of animals. In our opinion, it is important to update the species list and distribution of amphibians regularly in protected areas. Among the researchers who studied amphibian fauna of Ukrainian Roztochia were K. Tatarynov [21], N. Polushyna N., Shaitan S. [8], and L. I. Horban [4]. According to the data provided by L. I. Horban [4], fauna of forest amphibians of the Roztochia Biosphere Reserve is represented by 11 species, including Smooth Newt Lissotriton vulgaris (Linnaeus, 1758), Great Crested Newt Triturus cristatus (Laurenti, 1768), Fire-bellied Toad Bombina bombina (Linnaeus, 1761), Common Toad Bufo bufo (Linnaeus, 1758), Green Toad Bufotes viridis (Laurenti, 1768), European Tree Frog Hyla arborea (Linnaeus, 1758), Common Frog Rana temporaria (Linnaeus, 1758), Moor Frog Rana arvalis (Nilsson, 1842), Common Spadefoot Toad Pelobates fuscus (Laurenti, 1768), Marsh Frog Pelophylax ridibundus (Pallas, 1771) and Pool Frog Pelophylax lessonae (Camerano, 1882). However, due to the abundance of the two latter species and favorable conditions for the existence of their populations, we have grounds for considering that Edible Frog Pelophylax esculentus (Linnaeus, 1758) can also be found in this region. We can observe a similar situation in the publication of Polish scientists P. Stachyra, M. Tchórzewski [19], who made the inventory of vertebrate animals in Solska Forest in Roztochia region. Ten species of amphibians - T. cristatus, B. bombina, $P$. fuscus, $B$. bufo, B. viridis, $B$. calamita, $H$. arborea, $P$. lessonae, $R$. temporaria and $R$. arvalis - were found there.

The aim of this study was to update the list of amphibian species in three protected areas of Ukrainian Roztochia: the Roztochia Biosphere Reserve (Roztochia BR), the Yavorivskyi National Park (Yavorivskyi NP) and the Cholgini Ornithological Reserve (Cholgini OR). The objectives of our research were to compile the species list of amphibians on the study area, compare our records with literature data and amphibian collections of the Zoological Museum of Ivan Franko National University of Lviv, and describe the habitat peculiarities of the detected amphibians.

\section{MATERIALS AND METHODS}

Field studies were conducted during 2017-2020 on the territories of three protected areas of Ukrainian (Eastern) Roztochia: Roztochia BR, Yavorivskyi NP and Cholgini OR (Fig. 1). Roztochia BR was founded in 1984; it covers the area of 2084.5 ha. The area spans $8 \mathrm{~km}$ from north to south and $12 \mathrm{~km}$ from west to east. The territory of this reserve includes two sectors - Vereschytske and Stavchanske forestry. In the north (Stavchanske sector) and east (Vereschytske sector), the reserve borders Yavorivskyi NP $[7,16]$.

ISSN 1996-4536 (print) • ISSN 2311-0783 (on-line) • Біологічні Студії / Studia Biologica • 2020 • Том 14/№ 4 • С. 49-58 


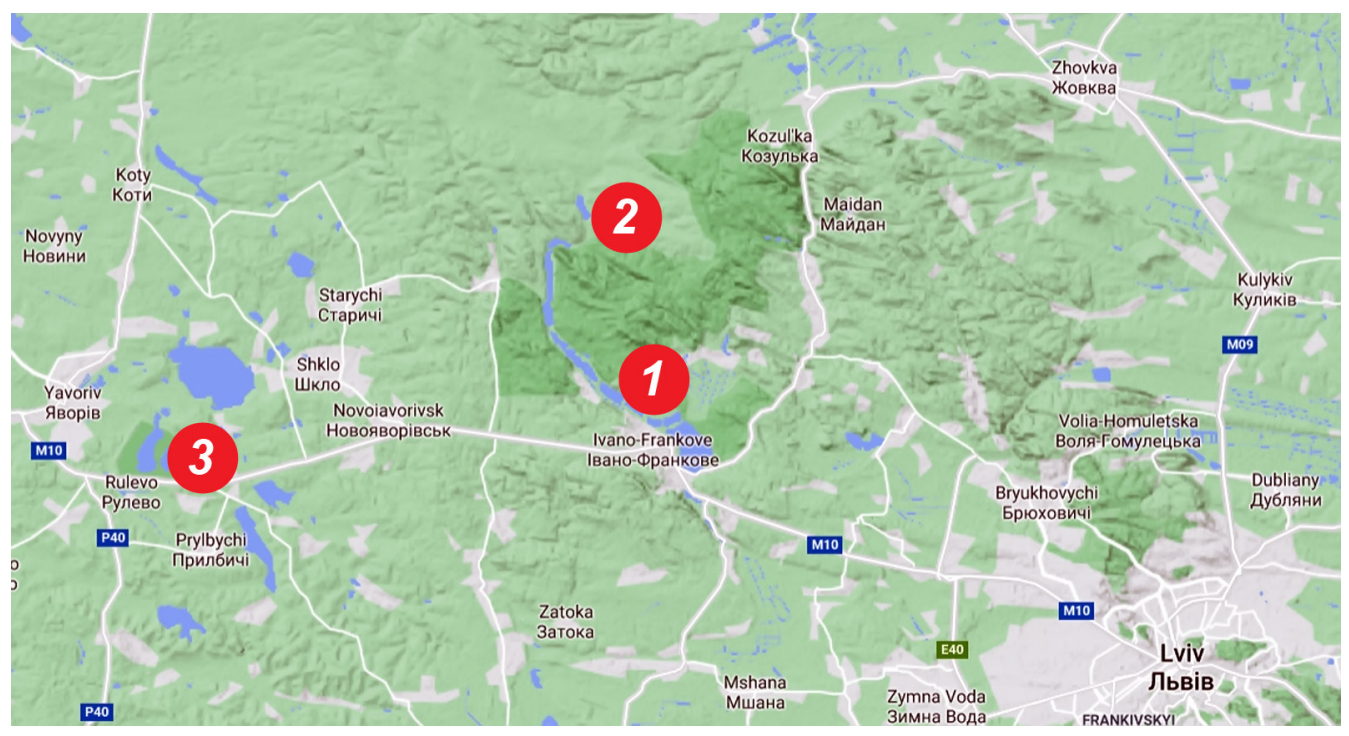

Fig. 1. Protected areas of Ukrainian Roztochia: 1 - Roztochia Biosphere Reserve; 2 - Yavorivskyi National Park; 3 - Cholgini Ornithological Reserve

Рис. 1. Природоохоронні території Українського Розточчя, на яких проводили дослідження: 1 - Природний заповідник Розточчя; 2 - Яворівський національний природний парк; 3 - Чолгинський орнітологічний заказник

Yavorivskyi NP was founded in 1998 and covers an area of 7108 ha. The territory of this park stretches like a crescent from Vereschytsia village of Yavorivskyi district to Krekhiv village of Zhovkivskyi district [5]. Its length from west to east is $12-13 \mathrm{~km}$, from north to south $-2.5-12 \mathrm{~km}$. In the south, this park borders Roztochia BR, in the north the Yavorivskyi military proving ground. The vast majority of territory is covered by hornbeam-oak, pine-oak, pine and alder forests [7].

Cholgini OR was founded in 1997 and is located on the edge of the south-westen spur of Ukrainian Roztochia near Cholgini village in Yavorivskyi district of Lviv region. The territory of the reserve is covered by a forest with two artificial reservoirs and a wetland complex [20].

We collected the material in several ways: catching the amphibians by hand and with herpetological nets, sampling the amphibians during the reproductive period by their vocalization, collecting crushed individuals on the roads, and catching the amphibians with frog fences that prevent them from crossing roads. Routes were chosen to meet the environmental requirements of amphibians - habitats near reproductive ponds, as well as forests and meadows with the feeding base. Based on the biotopes and amphibian diversity in them, we defined the biotope gradation of the amphibians on the study areas $[3,6]$. We also studied the amphibian collection in the Zoological Museum of Ivan Franko National University of Lviv in detail.

Sampling of crushed amphibians provided us with data about the species composition of the amphibian fauna. We regularly inspected the model section of the road T-1425 with the total lengths of $2.2 \mathrm{~km}$, which stretches between Yanivskyi Stav lake and a mixed forest (Fig. 2), as this road section crosses the main migratory routes of amphibians $[14,15]$.

ISSN 1996-4536 (print) • ISSN 2311-0783 (on-line) • Біологічні Студії / Studia Biologica • 2020 • Том 14/№ 4 • С. 49-58 


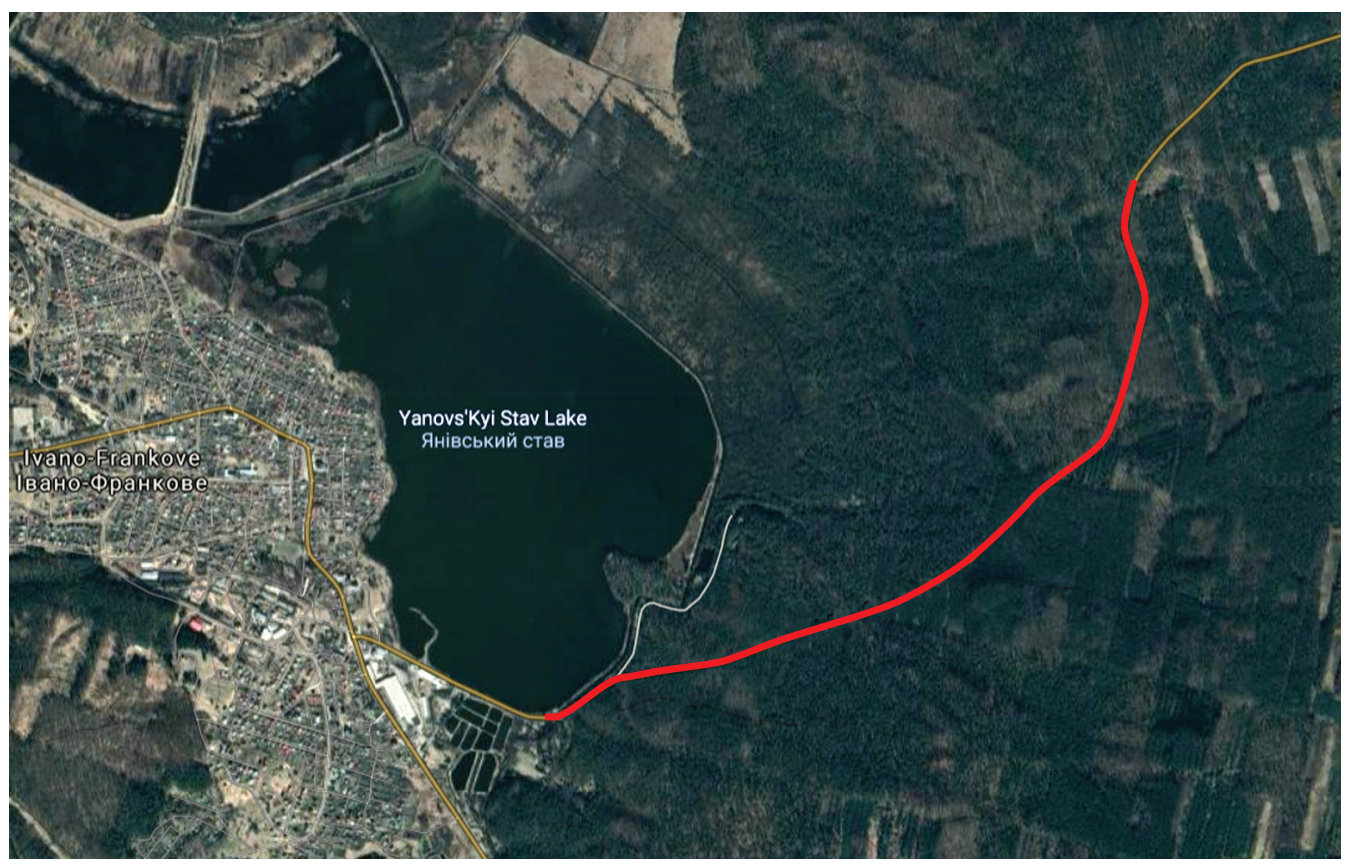

Fig. 2. Localization of model road section on the territory of Roztochia Biosphere Reserve, where model section of the road T-1425

Рис. 2. Локалізація модельної ділянки на території заповідника "Розточчя“, де - модельна ділянка на відтинку дороги Т-1425

Frog fences were installed during the amphibian migration period, when their terrestrial movement activity reached the peak. We installed fences twice during the spring period and once during the autumn period in that part of model area where amphibian mortality rates on the roads are the highest. The fences were installed on the two sides of the road, the total length of one barrier being $100 \mathrm{~m}$.

\section{RESULTS AND DISCUSSION}

During the field studies, we found 12 species of amphibians in 3 protected areas, in particular: in the Roztochia Biosphere Reserve - 10 species, in the Yavorivskyi National Park - 5 species, in the Cholgini Ornithological Reserve - 9 species. The list of the species representation is given in the Table.

According to the results, 4 of the 12 detected species inhabit all three protected areas. These are Eastern Tree Frog, Common Toad, Marsh Frog and Edible Frog. The details of the distribution and amphibian habitat peculiarities are discussed below.

Smooth Newt was detected in Roztochia BR and Cholgini OR. We found larvae of this newt in Roztochia BR in small reservoirs located between the forest and fish breeding ponds. Such distribution is normal for populations of this species because there are all necessary conditions for a successful course of the seasonal cycle: reproductive ponds with feeding base, as well as forest areas that are important feeding sites during the terrestrial phase of the amphibian seasonal cycle and suitable habitats for hibernation. This is confirmed by L. I. Horban [4] who noted that Smooth Newt is a forest species 
of Roztochia Biosphere Reserve. P. Stachyra and M. Tchórzewski [19] also reported findings about the distribution of $L$. vulgaris in Solska forest to the south of Lublin, which belongs to the territory of Roztochia.

Distribution of the detected amphibians in the protected areas of Ukrainian Roztochia Розподіл виявлених земноводних на заповідних територіях Українського Розточчя

\begin{tabular}{|c|c|c|c|}
\hline Protected area & $\begin{array}{c}\text { Roztochia } \\
\text { Biosphere Reserve }\end{array}$ & $\begin{array}{l}\text { Yavorivskyi } \\
\text { National Park }\end{array}$ & $\begin{array}{c}\text { Cholgini } \\
\text { Ornithological } \\
\text { Reserve }\end{array}$ \\
\hline Lissotriton vulgaris & + & - & + \\
\hline Triturus cristatus & + & - & + \\
\hline Bombina bombina & + & - & + \\
\hline Hyla orientalis & + & + & + \\
\hline Pelobates fuscus & + & - & + \\
\hline Bufo bufo & + & + & + \\
\hline Bufotes viridis & - & - & + \\
\hline Rana temporaria & + & - & - \\
\hline Rana arvalis & + & + & - \\
\hline Pelophylax ridibundus & + & + & + \\
\hline Pelophylax lessonae & - & - & + \\
\hline Pelophylax esculentus & + & + & + \\
\hline
\end{tabular}

We also detected Smooth Newt in Cholgini OR. We found approximately 20 juveniles during 2015-2017 on the wetlands and in small reservoirs nearby. These results are consistent with the literature, which maintains that during the terrestrial phase Smooth Newt prefers dry areas without big reservoirs nearby [9].

Great Crested Newt was found in the same protected areas as Smooth Newt. In Roztochia BR, we detected T. cristatus in medium size reservoirs located near fishbreeding ponds and forests. We found larvae and adults during 2017-2019. Records of this species can be found in literature as well $[4,8,19,21]$.

In Cholgini OR, we detected larvae of T. cristatus in small reservoirs, where we also found Marsh and Edible Frogs. According to literature, these species can successfully coexist in water and accomplish the water phase of the seasonal cycle (metamorphosis) $[9,18]$. However, Great Crested Newt occurred less frequently than Smooth Newt, which can be due to its higher ecological demands for habitats, primarily, reservoirs.

Fire-bellied Toad was found in Roztochia BR and Cholgini OR. In the former area, we detected adults in temporary ponds near fish breeding ponds and could hear mass male choirs (50-70 ind.) in these ponds in the summer and autumn periods. This seasonal activity is typical of the species and is confirmed by literature data [9, 11]. T. Hartel [1], T. Hartel and L. Demeter [2], based on the example of Yellow-bellied Toad B. variegata, consider the genus Bombina to be a "prolonged breeding species". The active male vocalization and their location in reservoirs even in the summer and autumn seasons is 
typical of this type of breeding. It is important to note that in 2006-2008 crushed individuals of Fire-bellied Toad were found in the model section of the road T-1425 [15], but during 2017-2020 we did not find any individuals of this species on this territory. We can assume that previously there were numerous small-size reservoirs in this area, which were used by the amphibians as breeding ponds. Presently, however, the reservoirs declined due to climate changes, thus this area is not favorable for some amphibians, including Fire-bellied Toad.

In Cholgini OR, we detected a small number of $B$. bombina. We found adults and juveniles in shallow wetland reservoirs, and could hear a single male choir in wetlands surrounded with reed thickets. Many researchers consider Fire-bellied Toad as the background species of Ukrainian Roztochia [4, 8, 21]. We observed a general trend towards a decrease in the number of populations due to habitat degradation [16].

Eastern Tree Frog was detected in Roztochia BR in reed thickets near fish breeding ponds and small-size temporary ponds. Male choirs could usually be heard. We were not able to detect a big number of $H$. orientalis in the study areas. Nevertheless, our results are consistent with general trends of distribution of this species on the study area $[4,14,15,21]$.

According to T. Hrynchyshyn, in Yavorivskyi NP, $H$. orientalis was detected by male vocalization near the recreation complex "Oselia Roztochia".

In Cholgini ornithological reserve, according to M. Skyrpan, Eastern Tree Frog was found near a wetland pond surrounded with reed thickets. This habitat is also typical of this frog. In literature, Eastern Tree Frog is known as European Tree Frog $\mathrm{H}$. arborea, because 10 years ago in Ukraine the single Hyla species was divided into two ones: European Tree Frog $H$. arborea inhabiting the Transcarpathians, and Eastern Tree Frog $H$. orientalis inhabiting the Fore-Carpathians [12].

Common Spadefoot Toad inhabits the two protected areas of Roztochia BR and Cholgini OR. In the first case, we detected living adults, larvae and crushed individuals. We found adults from spring to early autumn in sand biotopes near the ponds of several types: small ponds with a big number of underwater and surface vegetation, with the depth of 1-2 m, large fish breeding ponds, and roadside ditches with clear water. Many individuals were detected by reproductive underwater "knocking" of males. We observed small groups of larvae in similar ponds during the summer and the first part of autumn. Crushed individuals were found near habitats on the dirt road and in the model section of the road T-1425. All our records agree with the literature data on the distribution of $P$. fuscus on the territory of Ukrainian Roztochia $[4,19]$.

Common Toad is a common species for all three protected areas. In Roztochia BR, we detected $B$. bufo on several sites: mixed forests near the ponds, dirt roads near the settlements located around the reserve, and crushed individuals on the roads of different types. In addition, a few hundred of individuals of Common Toad were caught with frog fences and successfully transferred across the road. We have grounds for considering Common Toad as one of the three most common species that inhabit different types of habitats in Ukrainian Roztochia [4].

On the territory of Yavorivskyi NP, we detected adults during the summer periods in mixed forests located a few hundred metres from ponds and canals. In addition, we found crushed individuals on a dirt road near the recreation area.

In Cholgini OR, B. bufo was detected only once, in the sandy biotopes near ponds. All our findings are confirmed by literature data and the museum collection.

ISSN 1996-4536 (print) • ISSN 2311-0783 (on-line) • Біологічні Студії / Studia Biologica • 2020 • Том 14/№ 4 • С. 49-58 
Green Toad was detected on the territory of Cholgini OR. We found adult individuals in similar biotopes as Common Toad. According to the data provided by L. Horban [4], Green Toads inhabit forest systems of Ukrainian Roztochia, but less freequently than Common Toad. A specimen of Green Toad in the collection of the Zoological Museum of Ivan Franko National University of Lviv confirms the distribution of this species [22].

Common Frog was detected once in Roztochia BR, but as literature data indicates, $R$. temporaria inhabits all the reviewed territories. This species, together with $B$. bufo and $P$. esculentus, dominates over other species of amphibians. During 20172020 we found living individuals in mixed forests, near the ponds, caught in barriers and crushed on the roads of different types. Common Frog shows seasonal activity from May to November. It should be noted that despite its high numbers, during the last 10 years, Common Frog lost its reproductive sites - small-size and shallow ponds. As confirmation, we found reports about mortality of Common Frog on the same model area in 2006 and 2017-2019, where the number of individuals decreased twice [15].

Moor Frog was found in Roztochia BR and Yavorivskyi NP. In both protected areas, individuals of $R$. arvalis were present in mixed forests, so the biotope preference of this frog to forest areas is notable. This can be the reason why we have not found Moor Frog in Cholgini OR, where meadows with few forest areas are the most common biotopes. According to the literature, Moor Frog has a smaller number of populations than Common Frog in Ukrainian Roztochia and Ukraine in general [8, 9, 11].

Marsh Frog and Edible Frog are also common species for Ukrainian Roztochia. Identification of the species of Water Frogs Pelophylax can be difficult, especially during the juvenile phase. Nevertheless, individuals of Water Frogs were detected in all study areas; their distribution is confirmed by literature as well. We can explain such a high level of distribution by the accessibility of comfortable sites used during all periods of the seasonal cycle - a wide spectrum of reservoirs from small-size ponds with muddy water to large fish breeding ponds. These amphibians feel comfortable in ponds with fish and can spend the winter period in the same ponds [9].

Our field investigation confirmed the distribution of Pool Frog only in Cholgini OR. In the literature, we found information about an even distribution of $P$. lessonae on the whole territory of Ukrainian Roztochia, but the number of records of this species is smaller than that of other Water Frogs [4]. It should be noted that during the identification of the species of Water Frogs the chances of making a mistake are high. Moreover, many researchers consider that genetic analysis is the only certain method of identification of the Water Frogs.

\section{CONCLUSIONS}

Using methods of data analysis and our own field studies, we confirmed the distribution of 12 species of amphibians in three protected areas of Ukrainian Roztochia. In the Roztochia Biosphere Reserve and in the Cholgini Ornithological Reserve the amphibian species composition and distribution are quite similar. Thus, four species inhabit all three protected areas: Common Toad, Eastern Tree Frog, Marsh Frog and Edible Frog. The literature data about Natterjack Toad Epidalea calamita [10] indicate that this amphibian also inhabits Ukrainian Roztochia, but we have found no proof of it. In addition, we have described some habitat peculiarities of amphibians on the study area. Mixed forests, large fish breeding ponds, wetland ponds with reed thickets are

ISSN 1996-4536 (print) • ISSN 2311-0783 (on-line) • Біологічні Студії / Studia Biologica • 2020 • Том 14/№ 4 • С. 49-58 
comfortable habitats for many species of amphibians. A decrease in the number of species on the territory of the Yavorivskyi National Park can be due to a lack of water bodies, their degradation and the proximity of one of the largest military proving grounds in Europe, which limits amphibians in their choice of reproductive and trophic habitats.

\section{ACKNOWLEDGEMENTS}

The part of this work was done with the financial support of Rufford Fundation (Great Britain). Also, we would like to thank O. Reshetylo, V. Strus, Y. Strus, O. Shtyk, Y. Chaika, M. Skyrpan, I. Skyrpan, T. Hrynchyshyn, O. Peretiatkevych, M. Boikiv for the field data collection and recommendations.

\section{COMPLIANCE WITH ETHICAL STANDARDS}

Conflict of Interest: The authors declare that the research was conducted in the absence of any commercial or financial relationships that could be construed as a potential conflict of interest.

Human Rights: This article does not contain any studies with human subjects performed by the any of the authors.

Animal studies: All institutional, national and institutional guidelines for the care and use of laboratory animals were followed.

1. Hartel $T$. The long-term trend and the distribution of amphibian populations in a seminatural pond in the middle section of the Târnava-Mare Valley (Romania). Biota - Journal of Biology and Ecology, 2004; 4(1-2): 25-36.

Google Scholar

2. Hartel T., Demeter L. The breeding migration and population characteristics of a common toad (Bufo bufo) population in Târnava Valley, Romania. Transylvanian Review of Ecological and Systematical Research, 2005; 2: 145-154.

Google Scholar

3. Heyer W.R., Donnelly M.A., McDiarmid R.W., Hayek L.-A.C., Foster M.S. Measuring and Monitoring Biological Diversity: Standard Methods for Amphibians. 1994; Smithsonian Institution Press, Washington, DC: 384 p.

Google Scholar

4. Horban L.I. Fauna of forest amphibian species of "Roztochia" nature reserve. Scientific Bulletin of UNFU, 2010; 20(16): 218-224. (In Ukrainian)

Google Scholar

5. Hrekh V., Knyaz T., S. Kukurudza S. Functional meaning of the nature-protected areas in the river Vereschytsia basin. Visnyk of the Lviv University. Series Geography, 2009: 36: 96104. (In Ukrainian)

Crossref $\bullet$ Google Scholar

6. Lada H. A., Sokolov A. S. Methods of research of amphibians: Scientific-methodological manual. H. Derzhavin Tambov National University publishing house, 1999. 75 p. (In Russian)

7. Leonenko V.B., Popovych S. Yu., Kliestov M,L., Osypova M.O., Bardina I.M. Ukrainian nature reserve fund of state importance: manual. Kyiv, 1999: 240 p. (In Ukrainian)

8. Polushyna N., Shaitan S. Amphibians and Reptiles of Lviv Roztochia. Visnyk of the Lviv University. Series Biology, 1991; 21: 86-91. (In Ukrainian)

9. Pysanets Ye.M. Amphibians of Ukraine (guidebook for the determination of amphibians of Ukraine and neighbor countries). Kyiv, 2007. 192 p. (In Ukrainian)

10. Pisanets E.M., Litvinchuk S.N., Kurtyak F.F., Radchenko V.I. The amphibians of Ukrainian Red Book (Handbook - cadastre). Zoological Museum National Museum of Natural History, 2005; 230 p. (In Russian)

ISSN 1996-4536 (print) • ISSN 2311-0783 (on-line) • Біологічні Студії / Studia Biologica • 2020 • Том 14/№ 4 • С. 49-58 
11. Pysanets $Y$. The Ukrainian Amphibian Fauna: Issues of Diversity and Taxonomy. Communication 2. Anuran Amphibians (Anura). Collection of works of Zoological Museum, Kyiv, 2006; 38: 44-80. (In Russian)

12. Pysanets Y., Manilo V., Matveev A. The Preliminary Data of Green Tree Frog Hyla arborea and Eastern Tree Frog $H$. orientalis Variability from Eastern Europe (Amphibia, Hylidae). Ukrainian Herpetological society edition, 2011; 3: 128-138. (In Russian)

13. Pysanets E.M. The Tailed Amphibians (Amphibia: Caudata) Catalogue of collections. Zoological Museum National Museum of Natural History, 2003; 148 p. (In Russian)

14. Reshetylo O.S., Mykitchak T.I. Road Mortality of Amphibians (Amphibia) in Lviv Region: Problem Status and Estimating Criteria. Vestnik Zoologii, 2008; 42(4): 315-323. (In Ukrainian) Google Scholar

15. Reshetylo O.S., Rizun E.M., Rizun V.B. Problem of Mortality of Amphibians on the Roads and Ways to Solve It. Visnyk of the Lviv University. Series Biology, 2006; 42: 70-78. (In Ukrainian) Google Scholar

16. Reshetylo O., Stakh V., Osiyeva A.-A., Dykyy I., Andriyishyn B., Panchuk M., Tsaryk I. Mortality of Amphibians on the Roads of Lviv Region (Ukraine): Trend for the Last Decade. Vestnik Zoologii, 2019; 53(2): 131-140.

Crossref $\bullet$ Google Scholar

17. Rizun V.B., Heriak Y.M., Hirna A.Y. et al. Arthropoda of Roztochia Biosphere Reserve. State Museum of Natural History. Lviv, 2010. 395 p. (In Ukrainian) Google Scholar

18. Scherbak N., Scherban M. Amphibians and reptiles of Ukrainian Carpathians. Kyiv: Naukova Dumka, 1980. 268 p. (In Russian)

19. Stachyra P., Tchórzewski M. Diversity of vertebrate fauna of high and transitional peat bogs of the Solska Forest and of the Roztocze Region and suggestions for their protection. Teka Kom. Ochr. Kszt. Środ. Przyr., 2004; I: 214-219.

20. Strus Y., Shydlovskyi I. Migration of Waders (Aves: Charadrii) in the "Cholgini" Ornithological Reserve. Visnyk of the Lviv University. Series Biology, 2013; 61: 133-143. (In Ukrainian) Google Scholar

21. Tatarynov K. Vertebrate Fauna of West of Ukraine. Lviv: Lviv University Publishing House, 1973. P. 27-40. (In Ukrainian)

22. Zatushevskyy A.T., Shydlovskyy I.V., Bilyak I.T., Smirnov N.A., Hnatyna O.S. Catalogue of the amphibians of Zoological Museum of the Ivan Franko National University of Lviv. Zoological property series, 2017. 48 p. (In Ukrainian)

\section{ФАУНІСТИЧНИЙ ОГЛЯД ЗЕМНОВОДНИХ НА ЗАПОВІДНИХ ТЕРИТОРІЯХ УКРАЇНСЬКОГО РОЗТОЧЧЯ}

Б. О. Андріїшин

Львівський національний університет імені Івана Франка вул. Грушевського, 4, Львів 79005, Україна e-mail: bohdanoksalat@gmail.com

Вступ. Вивчення фауни земноводних як невід'ємних компонентів екосистем завжди $є$ актуальним і потребує постійного оновлення інформації, особливо на заповідних територіях. Проведено інвентаризацію амфібій, опрацювання літератури а також колекцій музеїв щодо трьох природно-заповідних територій: Природного заповідника "Розточчя”, Національного природного парку “Яворівський” та орнітологічного заказника “Чолгинський”.

ISSN 1996-4536 (print) • ISSN 2311-0783 (on-line) • Біологічні Студії / Studia Biologica • 2020 • Том 14/№ 4 • С. 49-58 
Матеріали і методи. Польові збори проводили класичними методами герпетологічних досліджень: маршрутним методом з відловом як вручну, так і за допомогою герпетологічного сачка, методом за вокалізацією, пошуком розчавлених земноводних на модельній ділянці, відловом земноводних у спеціальних захисних бар'єрах. Також проаналізовано літературні дані і опрацьовано музейні колекції фондів Зоологічного музею Львівського національного університету імені Івана Франка.

Результати. За літературними джерелами, батрахофауна цих трьох заповідних територій подібна і типова. Результати польових зборів трохи різняться, проте $€$ потреба у подальших тривалих дослідженнях. Відтак, на досліджуваних територіях виявлено 12 видів амфібій, що становить більше половини від загальної кількості амфібій України. Зокрема, це: тритон звичайний Lissotriton vulgaris, тритон гребінчастий Triturus cristatus, кумка червоночерева Bombina bombina, квакша східна Hyla orientalis, часничниця звичайна Pelobates fuscus, poпуха cipa Bufo bufo, ропуха зелена Bufotes viridis, жаба трав'яна Rana temporaria, жаба гостроморда Rana arvalis, жаба озерна Pelophylax ridibundus, жаба їстівна Pelophylax esculentus та жаба ставкова Pelophylax lessonae. Хвостатих земноводних виявлено два види, безхвостих - 10. На території Природного заповідника "Розточчя" виявлено 10 видів земноводних, Національного природного парку “Яворівський” - 5 видів, орнітологічного заказника "Чолгинський” - 9 видів земноводних.

Висновки. Згідно з результатами власних польових досліджень, чотири види земноводних населяють усі три заповідні території - це ропуха сіра, квакша східна, жаба озерна та жаба їстівна. Відносно невелике різноманіття земноводних на території НПП “Яворівський” можемо пояснити однотипністю оселищ і розташуванням там одного з найбільших військових полігонів у Європі, який обмежує земноводних у виборі репродуктивних і трофічних стацій. Особливої уваги заслуговують репродуктивні та трофічні оселища земноводних, які, на жаль, за останнє десятиліття стрімко деградують.

Ключові слова: амфібії, фрауна, заповідні території, Українське Розточчя, Природний заповідник “Розточчя”, Національний природний парк "Яворівський”, орнітологічний заказник "Чолгинський" 